\title{
PUBLICAR É PERECER?
}

Leonardo Arquimimo de Carvalho

IS PUBLISHING THE SAME AS PERISHING?

RESENHA

WATERS, LINDSAY. INIMIGOS DA ESPERANÇA: PUBLICAR, PARECER E O ECLIPSE DA ERUDIÇÃO. TRAD. LUIZ HENRIQUE DE Araújo Dutra. São Paulo: Ed. Unesp, 2006.

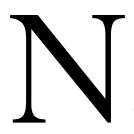

a condição de editor da Harvard University Press, Waters afirma ter avisado aos estudiosos e editores de humanidades que o futuro reserva pouco espaço para publicações na área e que deve ser construída uma estratégia para enfrentar o panorama. $\mathrm{Na}$ sua experiência, a partir da realidade das grandes universidades estadunidenses, o autor indica que elas direcionam grande parte de sua energia para a realização de operações que geram dividendos, e que as editoras universitárias, apesar de serem um péssimo negócio, deveriam produzir lucro.
Para Waters, florestas inteiras estão sendo derrubadas para agradar os gestores que acreditam ter melhorado os padrões com novas publicações - em 2000 as editoras universitárias estadunidenses publicaram 31 milhões de livros [sic]. Para o autor, a liberdade acadêmica era maior quando as instituições preservavam suas origens religiosas do que atualmente, quando é mediada pelas políticas de gestão das agências de financiamento, comportamento comum depois da $2^{\mathrm{a}}$ Guerra. "A vida acadêmica é um chamado, não um emprego", logo, distintas das relações que orientam a vida cotidiana. 
Mas a universidade foi refeita à luz das corporações estadunidenses, tornou-se uma marca que produz celebridades, "Oprah parece muito mais genuinamente investigativa e intelectual [...] que algumas das estrelas acadêmicas citadas nas páginas da seção 'Arts \& Ideas' do NewYork Times de sábado”.

Os fracassos editoriais são os registros inertes do "fracasso do lupem-professorado” em se comunicar. Porém, os vilões são os gestores que buscam a glória das suas universidade e buscam financiamento a qualquer custo, já que as universidades são corporações cujas ações são negociadas na Bolsa de Valores. Para o autor, há uma ideia de que depois de 11 de setembro os administradores não têm mais paciência com professores de humanidades e os jornalistas frequentemente divulgam em tom jocoso - com o aval do anti-intelectualismo próprio da sociedade estadunidense - os "temas bizarros" investigados nas humanidades.

Para o autor, a ampliação gigantesca do número de publicações, mesmo que competentes, acaba deslegitimando as boas publicações. Porém, o problema está na ausência de preocupação com a recepção do trabalho e no acesso à condição de professor como dependente da quantidade de publicações que poucos leem: [...] "há alguma contribuição para a erudição, se ninguém a lê?”. Ler os próprios artigos é uma ideia exótica!

De qualquer maneira, observa-se um conflito de gerações. Nos Estados Unidos, os docentes mais velhos tentam controlar os mais novos e estes começam a perceber que tal esse processo é injusto, "[...] quando membros do corpo docente mais velho impõem aos colegas mais jovens padrões para suas publicações que eles próprios não satisfizeram nem poderiam satisfazer". Waters afirma que a estabilidade deveria ser abolida e exigências uniformes de produtividade, garantidas. A Détente, de Mao, Nixon, De Gaulle e Brejnev, foi a representação ampliada, na década de 1960, da necessidade de subjugar os "filhos indisciplinados".

"A censura opera de formas misteriosas, como o processo de avaliação de submissões para publicação.” A história da avaliação pelos pares teve início nos séculos XVI e XVII, quando as melhores editoras ajudavam os autores a polir seus manuscritos. A academic peer review nasceu como mecanismo de censura e logo passou para os "[...] meandros da produção de valor acadêmico". A pergunta importante é: a avaliação feita pelos pares retomou sua qualidade de censura, ela limita a criatividade? Fingir que todos estão interessados no livre desenvolvimento de ideias é inadequado. "Não vamos mais fingir que os acadêmicos são intelectuais." Para Waters, há uma "sinergia" entre o sistema administrativo, que não quer saber da inovação ou do conteúdo, e os inimigos da inovação. "A sociedade contemporânea louva o inovador, mas ama realmente o conformismo”, e o indivíduo segue o juízo do grupo, mesmo errado. A ideia central é que "[...] temos a imensa sorte de estar dentro desse sistema, sabemos que recebemos boas cartas nesta rodada [...]”, mas, resolvemos não jogar com elas. Se não há jogo, 
não há perdedores, e é a autopreservação que define os "últimos homens".

Waters afirma que, no período atual, não é muito fácil diferenciar ousadia de timidez acadêmica. O abandono das pesquisas críticas e a renúncia à inovação é justamente o mais inovador. "Por isso, no momento atual, é difícil entender o que a erudição acadêmica realmente é." Esse autor utiliza o argumento de Rorty em favor do abandono das palavras que geram constrangimento entre os estudiosos de humanidades - "consciência”, "experiência”, "verdade”-, para demonstrar ousadia e, ao mesmo tempo, timidez hipócrita. Muitos acadêmicos eliminam o que outros consideram relevante aproximando-se do "mundo real". "Os professores não são mais uma espécie diferente - mendicantes e ascetas, gente com os olhos postos em outro mundo. São personagens astutos e maliciosos. E assim, vemos no reino acadêmico um espetáculo tão pouco edificante quanto o que testemunhamos na política [...]”.

Waters fortalece sua demonstração usando a pesquisa de Stanley Fish - How Milton Works - sobre o Areopagitica de Milton. Segundo Waters, Fish publicou a pesquisa citada com a pretensão de tornar todos os trabalhos futuros sobre Milton desnecessários. Como consequência, os estudiosos de Milton nos Estados Unidos, "[...] acataram essa demonstração de extrema confiança; e, desse modo, a timidez gerou mais timidez, na esteira do gesto de uma autoridade". Para Fish, livros não fazem diferença. Em nossa época, os livros escritos são os definitivos, são os últimos sobre qualquer obra ou autor. "Não admira que o jovem que aspira a uma carreira acadêmica não se arrisque ou esteja abandonando o barco.”

Para o autor, tanto Fish quanto Rorty representam a tendência dominante ao negativismo na academia. "A ideia que agora domina a academia é a de evitar ideias." "[...] O negócio é reduzir o papel do indivíduo a nada.” Para muitos acadêmicos, a curiosidade mata gatos e, mais ainda, acadêmicos. "O bom profissionalismo é marcado por uma virtude delimitada e enclausurada. Se acharmos que o acadêmico deve ser um intelectual, simplesmente estaremos errados." Waters aposta na capacidade redentora dos livros.

A pergunta necessária é: qual a relação entre pensamento, erudição e publicação? Para Waters, é possível ser um pensador e nada publicar. Como eruditos "[...] podemos estudar atentamente durante anos um corpo de informações [...] e não apresentar nenhum resultado", assim admitindo "[...] que uma pesquisa séria levou alguém a concluir que não há nada a dizer".

"Em nossa fúria escolástica para empanturrar as bibliotecas até que explodam de publicações, algo se perdeu." Pergunta Waters, o que fazer agora, que as bibliotecas não compram livros e eles não são lidos ou avaliados? As publicações eletrônicas piorarão a situação e a valorização do livro, e os princípios por trás da cultura dele são necessários. "Durante anos fiquei intrigado com os estudiosos que não querem publicar, que praticamente sequer falam sobre o que sabem.” 
O que tem valor, possivelmente, será ignorado. Waters lembra que Picasso escondeu Demoiselles d'Avignon por seis anos temendo o opróbrio. É necessário mostrar as coisas no tempo certo, mas não há independência em relação às normas rígidas para as publicações. "É como se as escolas estivessem dizendo implicitamente que, para conseguir a estabilidade, temos que provar que não somos mentes independentes, que nos submetemos às regras e aos objetivos de alta produtividade." As melhores publicações, afirma Waters, são as produzidas sem pressa. "Há gente demais desesperada em publicar, e muita pouca gente esperando o momento propício [...].”

A pressão é gigantesca. Rogers Albritton costumava rasgar suas notas pessoais para palestras para evitar que as editassem como livro. Seus amigos conspiraram para conduzi-lo à presidência da American Philosophical Association Pacific Division, como consequência, os pronunciamentos anuais, obrigatórios, foram publicados nos anais da entidade. É lamentável, mas os que têm muito a dizer são os mais relutantes em dizê-lo, "[...] esqueçam os tagarelas". "Jonh Rawls foi um gago - e sei porque, durante anos, tentei sem êxito publicá-lo - que se manteve totalmente desinteressado em publicar seu trabalho."

Waters indica como relevante o conflito entre a oralidade e a escrita. Mas o problema é que os homens são tentados à escravidão - de outrem, de pensamentos passados, da reificação da escrita ou da publicação. Waters indica a necessidade de repensar o vício das publicações já que ele é um grande insulto à dignidade do pensamento. Para ele, é necessário dizer "não" aos gestores, recuperar a qualidade das revistas evitando os editores gananciosos. Ainda, temos que estar prontos para explicar nossos trabalhos e não achar insultante. "Precisamos reorientar as humanidades na universidade.” "[...] Nas humanidades, temos de erradicar a atitude de complacência perante o sistema, venha ela da parte dos administradores, venha de nós próprios [...]”. 